\title{
Every child deserves a home
}

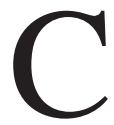

hildren who have a government as their parent, no matter how well-intentioned or necessary that arrangement is, are often damaged by it. ${ }^{1}$ The evidence of this harm is extensive and consistent. It's time we made it a priority in Canada to find permanent homes for children and youth in the care of child welfare agencies.

This November marks the 20th anniversary of the United Nations Convention on the Rights of the Child, which is ratified by 193 countries, including Canada. Signatories of the Convention recognize that "the child, for the full and harmonious development of his or her personality, should grow up in a family environment, in an atmosphere of happiness, love and understanding." Yet each year in Canada, of the estimated 30000 to 40000 children in care who are legally available for adoption, only 2300 are adopted on average. Most children "age out" of the system without permanent families.

The cost is high. Youth in care are 17 times more likely to be hospitalized for mental health issues than the general public, according to Kids, Care and Crime, a report published in February 2009 by British Columbia's representative of children and youth and the provincial health officer. ${ }^{2}$ By 21 years of age, $41 \%$ of children and youth in care have been in contact with the justice system, compared to only $6.6 \%$ of the general population in the same age group. Of those in contact with the justice system, $72 \%$ have been reported, while in school, to have had serious mental illness, behavioural problems or fetal alcohol spectrum disorders.

This is not the case for most children who are adopted from care. Over time and with effective post-adoption support, most adoptees become attached to their new families and their problems diminish. ${ }^{3}$ Their quality of life improves, along with their sense of self.

Yes, we should focus more on reducing the number of children who need to be taken into government care by providing birth families with effective forms of social and educational support. But even with optimal services, there will always be some children who need the system.

Warehousing children in foster care - no matter how caring the warehouse - is simply not good enough. Adoption through the public system is far less expensive and results in far better outcomes for children than long-term foster care, according to a recent Ontario report on infertility and adoption entitled Raising Expectations. ${ }^{4}$

Incredible inroads are being made by governments that have recognized this truth and begun providing the resources needed to find permanent homes for children in care. In 2002, the United Kingdom set a target to increase the number of such children placed for adoption by $40 \%$, and supported that target with an increased budget. ${ }^{5}$ The result was that 1000 more children were adopted in England during the period 2003-2004 than during 1999-2000 — an increase of $37 \% .^{6}$

In several American states, agencies whose sole mandate is to find permanent homes for older children and teenagers are being hired by child welfare authorities. One such agency in New York City, You Gotta Believe, is placing 50-60 young people over the age of 18 in permanent homes every year. Here in Canada, the New Brunswick Adoption Foundation was created in 2002 to increase adoption awareness in that province, with 25 social workers hired to focus on permanent placements. Adoption rates in New Brunswick jumped $300 \%$, from an average of 25 children per year before 2002 to about 100 children per year.

But most provincial governments are lagging behind. Just $2 \%$ of the child welfare budget in Ontario, for example, goes toward finding adoptive homes. ${ }^{4}$ Children aged six and older, who make up the majority of children in care, are often considered unadoptable simply because of their age.

Let's change such outdated thinking and make it easier for Canadians to open their homes to children and youth in care, whether that be through adoption, legal guardianship, customary care or kinship care.

First, to drive change, we need to agree that a specific amount of time spent in care of the state - two years is a reasonable benchmark - constitutes an adverse outcome. To improve accountability, we need to insist on public reporting of system outcomes, good or bad.

Second, we need to make it easier for potential adoptive parents to learn about children who might be good matches. All levels of government should contribute to programs (e.g., national and regional photo-listing services) that support this goal.

Third, interprovincial adoption should be made easier than international adoption. The provinces and territories need to draft memoranda of understanding that will allow families to adopt out-of-province children who would not otherwise find permanent homes.

Fourth, we need to dismantle legal barriers to adopting children who still have contact with their birth families, as 
proposed in Quebec. For instance, a birth family's courtordered access should not automatically prevent adoption. Open adoption has become more common, and our laws need to keep pace with current realities.

And finally, once children are placed in permanent homes, we must ensure that the supportive resources needed to treat their mental and physical health issues move with them.

Our complacency harms not only children in care but also their children. Ultimately, we will all pay.

\section{Laura Eggertson BJ}

News Correspondent, CMAJ

Noni MacDonald MD MHSc

Section Editor, Public Health, CMAJ

Cindy L. Baldassi LLM

$\mathrm{PhD}$ candidate, University of British Columbia, Faculty of Law

Paul C. Hébert MD MHSc

Editor-in-Chief, CMAJ

Editorial advisory team: Ken Flegel MDCM MSc and Joan Ramsay BA

Competing interests: Laura Eggertson is the parent of two children adopted from Ontario's child welfare system. She has trained adoptive parent support leaders for the Adoption Council of Canada. Cindy L. Baldassi works in adoption, reproductive technologies and parentage law, and has written about adoption disclosure and indigenous customary adoption. She is also an adoptee. Please see www.cmaj.ca /misc /edboard.shtml for the statements of Noni MacDonald and Paul Hébert.

Cite as CMAJ 2009. DOI:10.1503/cmaj.091968

\section{REFERENCES}

1. Trupin EW, Tarico VS, Low BP, et al. Children on child protective service caseloads: prevalence and nature of serious emotional disturbance. Child Abuse Negl 1993; 17:345-55

2. Representative for Children and Youth of British Columbia. Kids, crime and care Health and well-being of children in care: youth justice experiences and outcomes. Victoria (BC): Office of the Provincial Health Officer; 2009. Available: www.llbc .leg.bc.ca/public/pubdocs/bcdocs/454658/youth_justice_joint_rpt_final_.pdf (accessed 2009 Nov. 9).

3. Rushton A, Treseder J, Quinton D. An eight-year prospective study of older boys placed in permanent substitute families: a research note. $J$ Child Psychol Psychiatry 1995;36:687-95.

4. Ontario Ministry of Children and Youth Services. Raising expectations: recommendations of the Expert Panel on Infertility and Adoption. Toronto (ON): The Ministry; 2009. Available: www.children.gov.on.ca/htdocs/english/documents /infertility/raisingexpectationsenglish.pdf (accessed 2009 Nov. 9).

5. Rushton A. The adoption of looked after children: a scoping review of research. London (UK): Social Care Institute for Excellence; 2003. Available: www.scie.org .uk/publications/knowledgereviews/kr02.pdf (accessed 2009 Nov. 6).

6. Statistics of Education: Children looked after in England (including adoptions and care leavers): 2003-2004. London (UK): National Statistics Bulletin; 2005. Issue No. 01/05. Available: www.dcsf.gov.uk/rsgateway/DB/SBU/b000552 /CLAbulletin2003-04final.pdf (accessed 2009 Nov. 6). 